\title{
Altered Composition of Urinary Heparan Sulfate in Patients with COPD
}

\author{
CHRIS $H$. van de LEST, ELLY M. VERSTEEG, JACQUES H. VEERKAMP, JO H. BERDEN, \\ JACOB van den BORN, LEO HEUNKS, JAN-WILLEM J. LAMMERS, CEES L. van HERWAARDEN, \\ P. N. RICHARD DEKHUIJZEN, and TOIN H. van KUPPEVELT
}

Departments of Biochemistry, Nephrology, and Pulmonary Diseases, University of Nijmegen, Nijmegen, the Netherlands

\begin{abstract}
In patients with emphysema the integrity of the extracellular matrix (connective tissue skeleton) is compromised. In this study we analyzed glycosaminoglycans, which are main constituents of this matrix, in urines from patients with chronic obstructive pulmonary disease (COPD)/emphysema. Glycosaminoglycans (GAGs) were purified by anion exchange chromatography and quantified using the 1,9-dimethylmethylene blue assay. Heparan sulfate (HS) was assayed using three different chemical methods: digestion with heparitinase or with nitrous acid and by use of an adapted 1,9-dimethylmethylene blue assay. A specific epitope on the HS molecule, defined by the monoclonal antibody JM403, was determined using an inhibition enzyme immunoassay. In patients with COPD total urinary glycosaminoglycan and HS content were not altered. The JM403 epitope of HS, however, was greatly decreased in patients ( 0.6 versus 4.1 units $/ \mathrm{mg}$ creatinine for control subjects, $p<0.0001)$. A similar pattern was observed when patients with bronchial carcinoma with and without emphysema were compared $(0.4$ versus 2.4 units $/ \mathrm{mg}$ creatinine respectively, $p<0.0005$ ). Patients with sarcoidosis did not show a decreased epitope content. These results indicate a structural change or an altered processing of the HS molecule in patients with emphysema. Taking into consideration the importance of HS for the stability of the alveolar extracellular matrix, this change may be associated with the pathogenesis of emphysema. van de Lest CH, Versteeg EM, Veerkamp IH, Berden JH, van den Born I, Heunks L, Lammers J-WJ, van Herwaarden CL, Dekhuijzen PNR, van Kuppevelt TH. Altered composition of urinary heparan sulfate in patients with COPD.

AM I RESPIR CRIT CARE MED 1996; 154:952-8.
\end{abstract}

Airspace enlargement, destruction of alveoli, and loss of elasticity are the hallmarks of pulmonary emphysema. A loss of the integrity of the extracellular matrix is probably underlying the disease. The vast majority of research has focused on elastin. Breakdown of elastin, however, has not been unequivocally demonstrated in human emphysematous lung tissue (1), nor is there consensus about an increase in elastin-derived peptides in serum or urine of patients. Elevated levels of elastin-derived peptides have $(2,3)$, and have not (4-6) been observed. In laboratory animals, emphysema can be induced with and without destruction of elastin (1).

Other alveolar extracellular matrix molecules like collagens, proteoglycans, laminin, and fibronectin may also be of importance in the pathogenesis of emphysema. Proteoglycans deserve special attention because they play a key role in the integrity of

(Received in original form February 23, 1994 and in revised form February 22, 1996) C. H. van de Lest, E. M. Versteeg, J. H. Veerkamp, and T. H. van Kuppevelt were supported by Grant 89.14 from the Dutch Asthma Foundation.

1. H. Veerkamp, J. H. Berden, and I. van den Born were supported by Grant C90.1040 from the Dutch Kidney Foundation and Grant 3MH1-CT92-1766 from the EC Biomed I program.

Correspondence and requests for reprints should be addressed to T. H. van Kuppevelt, Department of Biochemistry, University of Nijmegen, P.O. Box 9101 , $6500 \mathrm{HB}$ Nijmegen, the Netherlands.

Am J Respir Crit Care Med Vol 154. pp 952-958, 1996 the alveolar wall. They are involved in the fibrillogenesis and mechanical characteristics of elastin and collagen (7-9), they bind and modulate growth factors and cytokines (10), and they are powerful inhibitors of proteases, including human leukocyte elastase (11-13).

Proteoglycans are macromolecules consisting of a core protein to which negatively charged glycosaminoglycans (GAGs) are attached. GAGs are a class of long unbranched polysaccharides, consisting of repeating disaccharides of which one is an amino sugar residue and the other an uronic acid residue. In the alveolar wall, different types of GAGs are present $(14,15)$, including heparan sulfate (HS) which is located in basement membranes and on cell surfaces. Alterations in lung GAGs have been described in experimental as well as human emphysema (16-21). The results of these studies, however, are contradictory, likely due to differences in experimental setup. In human lung, for instance, an increase (16) and a decrease (17) in the percentage of hyaluronic acid have been found; also in human lung an increase (18) and no increase (19) in the glucosamine/galactosamine ratio has been demonstrated.

In this study we have analyzed the urinary excretion of GAGs from patients with chronic obstructive pulmonary disease (COPD) emphysema, with special emphasis on HS. For comparison, we also studied patients with bronchial carcinoma with and without emphysema, and patients with sarcoidosis. It was found that the presence of a specific epitope of HS is considerably reduced in urine of emphysematous patients, despite an unchanged total HS content. 
TABLE 1

PHYSIOLOGIC DATA OF PATIENTS WITH COPD

\begin{tabular}{|c|c|c|c|c|c|c|c|c|c|c|}
\hline $\begin{array}{l}\text { Patient } \\
\text { Code }\end{array}$ & $\begin{array}{c}\text { Age }(y r) \\
\text { Sex }\end{array}$ & $\begin{array}{c}\mathrm{BMI} \\
\left(\mathrm{kg} / \mathrm{m}^{2}\right)\end{array}$ & $\begin{array}{c}\text { TLC } \\
\text { (\% pred) }\end{array}$ & $\begin{array}{c}\text { RV } \\
\text { (\% pred) }\end{array}$ & $\begin{array}{c}\mathrm{FEV}_{1} \\
\text { (\% pred) } \\
\text { before } \mathrm{S} \\
\end{array}$ & $\begin{array}{c}\text { FEV } \\
\text { (\% pred) } \\
\text { after } \mathrm{S} \\
\end{array}$ & $\begin{array}{c}\text { Kco } \\
\text { (\% pred) }\end{array}$ & $\begin{array}{l}\mathrm{PaO}_{2} \\
(\mathrm{kPa})\end{array}$ & $\begin{array}{l}\mathrm{PaCO}_{2} \\
(\mathrm{kPa})\end{array}$ & $\begin{array}{l}\text { Pack- } \\
\text { years }\end{array}$ \\
\hline 16 & $51, \mathrm{M}$ & 23.3 & 102 & 97.5 & 35 & 42 & 11 & 7.09 & 4 & 21 \\
\hline$B R$ & $63, M$ & 19.6 & 111 & 135 & 43 & 49 & 54 & ND & ND & 30 \\
\hline 0 & $71, M$ & 24.7 & 138 & 211 & 31 & 31 & 54 & ND & ND & 20 \\
\hline HS & $71, \mathrm{~F}$ & 24.6 & 104 & 67 & 45 & 55 & 31 & 12.1 & 4.6 & 5 \\
\hline JI & $65, M$ & 23.4 & 104 & 135 & 23 & 23 & 41 & 9.5 & 4.7 & 40 \\
\hline v & $82, \mathrm{M}$ & 29.6 & 132 & 177 & 46 & 54 & 69 & 6.8 & 6.5 & 40 \\
\hline$H X$ & $56, \mathrm{~F}$ & 24.9 & 125 & 171 & 19 & 21 & 20 & 8.1 & 5.9 & 40 \\
\hline IA & $57, F$ & 24.7 & 94 & 136 & 28 & 27 & 50 & 7.8 & 8.1 & 30 \\
\hline JB & $70, M$ & 18.1 & 106 & 102 & 30 & 32 & 53 & 7.9 & 5.7 & 0 \\
\hline JH & $60, M$ & 20.5 & 110 & 196 & 11 & 14 & 28 & 8.7 & 6.2 & 30 \\
\hline 10 & $62, \mathrm{M}$ & 29 & 121 & 216 & 26 & 24 & 67 & 14.2 & 4.3 & 35 \\
\hline $\mathrm{HZ}$ & $50, M$ & 20.1 & 110 & 224 & 31 & 37 & 58 & 11 & 4.6 & 30 \\
\hline H & $65, M$ & 28.7 & 107 & 110 & 41 & 46 & 40 & 9.2 & 5.1 & 45 \\
\hline $\mathrm{HU}$ & $74, M$ & 20.9 & 140 & 174 & 31 & 33 & 38 & 11.9 & 4.9 & 20 \\
\hline JE & $67, M$ & 21.3 & 117 & 139 & 43 & 43 & 29 & 10.3 & 4.9 & 35 \\
\hline HP & $70, M$ & 22.9 & 113 & 152 & 21 & 21 & 49 & 9.7 & 4.9 & 13 \\
\hline $\mathrm{HV}$ & $77, M$ & 27.4 & 109 & 153 & 24 & 24 & 73 & 8.4 & 6.3 & 12 \\
\hline$w$ & $61, \mathrm{M}$ & 17.4 & 117 & 198 & 19 & 20 & 21 & 7.8 & 6.2 & 40 \\
\hline$H R$ & $79, \mathrm{M}$ & 24.7 & 94 & 96 & 55 & 57 & 61 & 11.1 & 4.9 & 10 \\
\hline HT & $60, F$ & 18 & 116 & 159 & 26 & 33 & 35 & 8.9 & 5.0 & 25 \\
\hline
\end{tabular}

Definition of abbreviations: $\mathrm{BMI}=$ body mass index (weight/length ${ }^{2}$ ); TLC = total lung capacity; $\mathrm{RV}=$ residual volume; $\mathrm{FEV},=$ forced expiratory volume in one second; $S=$ salbutamol; $\mathrm{KCO}=$ difusion capacity for carbon monoxide corrected for alveolar volume; $\%$ pred $=$ percentage of the predicted value; ND = not determined.

\section{METHODS}

\section{Patients and Control Subjects}

Three groups of patients and control subjects were studied: Group 1, patients with COPD and matched control subjects; Group 2, patients with bronchial carcinoma with and without emphysema; and Group 3, patients with sarcoidosis and matched control subjects.

Physiologic data for individual patients are given in Tables 1-3. In all groups subjects with cardiovascular, alcohol-related, or renal diseases were excluded. Patients with $\alpha_{1}$-antitrypsin deficiency were also excluded. Control subjects did not show any sign of pulmonary disease, nor any other disease. Patients and control subjects were matched for sex, age, and smoking habit. All subjects were studied according to guidelines of the Committee of Medical Ethics of the University Hospital Nijmegen and gave informed consent.

Static and dynamic lung function tests were performed with a wet spirometer and with a closed-circuit helium-dilution method (Pulmonet III; Sensormedics, Bilthoven, the Netherlands). Diffusion capacity $(\mathrm{KCO})$ was measured with the single breath-holding carbon monoxide method (Sensormedics 2450) and was corrected for actual hemoglobin. Measurements were performed at least $12 \mathrm{~h}$ after smoking. Predicted spirometric values were derived from the European Community for Steel and Coal (E.C.S.C.) standards (22).

Arterial blood samples were taken after the patients had been sitting for at least $15 \mathrm{~min}$. $\mathrm{PaO}_{2}$ and $\mathrm{PaCO}_{2}$ were measured with a Corning $\mathrm{Ph}$ 127 blood gas analyzer (Corning Glass, Medfield, MA).

TABLE 2

PHYSIOLOGIC DATA OF PATIENTS WITH BRONCHIAL CARCINOMA, WITH OR WITHOUT EMPHYSEMA

\begin{tabular}{|c|c|c|c|c|c|c|c|c|c|}
\hline $\begin{array}{l}\text { Patient } \\
\text { Code }\end{array}$ & $\begin{array}{c}\text { Age }(y r) \\
\text { Sex }\end{array}$ & $\begin{array}{c}\text { TLC } \\
\text { (\% pred) }\end{array}$ & $\begin{array}{c}\text { RV } \\
\text { (\% pred) }\end{array}$ & $\begin{array}{c}\text { FEV } 1 \\
\text { (\% pred) } \\
\text { before } S\end{array}$ & $\begin{array}{c}\text { FEV } \\
\text { (\% pred) } \\
\text { after } S\end{array}$ & $\begin{array}{c}\mathrm{KCO} \\
(\% \text { pred })\end{array}$ & $\begin{array}{l}\mathrm{PaO}_{2} \\
(\mathrm{kPa})\end{array}$ & $\begin{array}{c}\mathrm{PaCO}_{2} \\
(k P a)\end{array}$ & $\begin{array}{l}\text { Pack- } \\
\text { years }\end{array}$ \\
\hline \multicolumn{10}{|c|}{ Patients with bronchial carcinoma and emphysema } \\
\hline 15 & $64, F$ & 113 & 119 & 44 & 47 & 53 & 8.1 & 5.6 & 40 \\
\hline 67 & $60, M$ & 94 & 114 & 61 & 58 & 61 & 10.6 & 5.3 & 35 \\
\hline 72 & $75, M$ & 136 & 120 & 64 & 68 & 78 & 10.6 & 5.1 & 10 \\
\hline 44 & $58, M$ & 116 & 157 & 64 & 67 & 68 & 8.3 & 4.6 & 20 \\
\hline 71 & $66, M$ & 112 & 105 & 42 & 39 & 46 & 8.0 & 5.5 & 40 \\
\hline 45 & $70, M$ & 96 & 100 & 75 & 74 & 71 & 8.9 & 5.4 & 50 \\
\hline 58 & $77, \mathrm{M}$ & 109 & 95 & 80 & 78 & 52 & 10.3 & 5.4 & 15 \\
\hline 18 & $78, M$ & 132 & 89 & 70 & 71 & 54 & 9.5 & 4.9 & 20 \\
\hline \multicolumn{10}{|c|}{ Patients with bronchial carcinoma, without emphysema } \\
\hline 21 & $58, \mathrm{M}$ & 79 & 65 & 76 & 76 & 120 & 13.5 & 5.2 & 20 \\
\hline 65 & $68, M$ & 102 & 106 & 75 & 75 & 86 & 7.0 & 5.48 & 20 \\
\hline 37 & $72, \mathrm{M}$ & 96 & 86 & 104 & 104 & 123 & 9.8 & 4.8 & 10 \\
\hline 41 & $96, M$ & 93 & 103 & 75 & 75 & 90 & 7.7 & 5.0 & 25 \\
\hline 3 & $68, M$ & 85 & 78 & 71 & 75 & 89 & 10.6 & 4.5 & 30 \\
\hline 8 & $81, M$ & 103 & 81 & 110 & 115 & 83 & 11.2 & 4.9 & $-\star$ \\
\hline 56 & $64, M$ & 66 & 65 & 47 & 50 & 93 & 9.2 & 5.6 & 40 \\
\hline 39 & $63, M$ & 98 & 110 & 71 & 75 & 104 & 8.2 & 5.3 & 30 \\
\hline
\end{tabular}

For definition of abbreviations, see Table 1.

* Nonsmoker. 
TABLE 3

PHYSIOLOGIC DATA OF PATIENTS WITH SARCOIDOSIS

\begin{tabular}{|c|c|c|c|c|c|c|c|c|}
\hline $\begin{array}{l}\text { Patient } \\
\text { Code }\end{array}$ & $\begin{array}{c}\text { Age }(y r) \\
\text { Sex }\end{array}$ & $\begin{array}{c}\mathrm{BMI} \\
\left(\mathrm{kg} / \mathrm{m}^{2}\right)\end{array}$ & $\begin{array}{c}\text { TLC } \\
\text { (\% pred) }\end{array}$ & $\begin{array}{c}\text { RV } \\
\text { (\% pred) }\end{array}$ & $\begin{array}{c}\text { FEV }_{1} \\
(\% \text { pred })\end{array}$ & $\begin{array}{c}\text { KCo } \\
\text { (\% pred })\end{array}$ & $\begin{array}{l}\text { Pack- } \\
\text { years }\end{array}$ & $\begin{array}{c}\text { OCS } \\
(m g / d a y)\end{array}$ \\
\hline$\$ 2$ & $32, M$ & 26.5 & 103 & 92 & 103 & 82 & $-^{*}$ & 25 \\
\hline$\$ 3$ & $55, \mathrm{~F}$ & 28.7 & 103 & 75 & 107 & 117 & - & -+ \\
\hline S4 & $41, F$ & 23.2 & 77 & 72 & 66 & 101 & - & - \\
\hline S5 & $38, F$ & 24.7 & 90 & 66 & 83 & 119 & - & 5 \\
\hline 56 & $25, \mathrm{~F}$ & 21.5 & 116 & 122 & 110 & 76 & - & - \\
\hline 57 & $32, F$ & 30.9 & 85 & 76 & 91 & 146 & - & - \\
\hline 58 & $31, M$ & 24.2 & 77 & 58 & 90 & 127 & 3 & - \\
\hline 59 & $60, F$ & 37.3 & 87 & 5 & 109 & 131 & - & 10 \\
\hline$\$ 10$ & $61, F$ & 22.6 & 82 & 82 & 80 & 125 & - & 5 \\
\hline$\$ 11$ & $33, \mathrm{M}$ & 20.9 & 78 & 79 & 53 & 59 & 16 & 10 \\
\hline$\$ 12$ & $41, M$ & 24.5 & 93 & 83 & 97 & 125 & - & 5 \\
\hline$\$ 13$ & $59, F$ & 27.1 & 93 & 71 & 111 & 125 & - & - \\
\hline$S 14$ & $28, F$ & 25.9 & 80 & 64 & 79 & 96 & 15 & - \\
\hline S15 & $43, M$ & 27.4 & 90 & 73 & 86 & 106 & - & - \\
\hline$\$ 16$ & $32, F$ & 19.8 & 80 & 111 & 91 & 95 & - & - \\
\hline
\end{tabular}

Definition of abbreviations: OCS = oral corticosteroids. All other abbreviations, as defined in Table 1.

* Nonsmoker.

$\uparrow$ No OCS.

Group 1: Patients with COPD and control subjects. Physiologic data of all individual patients are shown in Table 1. Patients were characterized by severe airways obstruction and (in most cases) hyperinflation, and a reduced KCo. No improvement of FEV, was observed after inhalation of $400 \mu \mathrm{g}$ salbutamol. Patients were in a stable condition, without exacerbations during the preceding $3 \mathrm{mo}$. All subjects used inhaled $\beta_{2}$-sympathomimetics and/or anticholinergics. Fourteen patients $(70 \%)$ used inhaled corticosteroids in a mean dosage of $630 \pm 240 \mu \mathrm{g}$ daily. None used theophylline or oral corticosteroids. Lung function data and body measures of control subjects are given in Table 4 .

Group 2: Patients with bronchial carcinoma with and without emphysema. Physiologic data of all individual patients are shown in Table 2. Patients were characterized by a recently detected and histologically proven bronchial carcinoma (in all cases squamous cell carcinoma). Patients with bronchial carcinoma without emphysema had no radiographic or histologic signs of emphysema, and total lung capacity and diffusion capacity were within predicted mean $\pm 1.64 \mathrm{SD}$.

Group 3: Patients with sarcoidosis and control subjects. Physiologic data of all individual patients are shown in Table 3. Patients had histologically proven sarcoidosis stage 2 (mediastinal and/or hilar lymphadenopathy and radiographic signs of interstitial involvement). Six of 15 patients used oral corticosteroids in a dosage of 5 to $25 \mathrm{mg} / \mathrm{d}$, whereas the other patients did not receive any medication. Lung function data and body measures of control subjects are given in Table 5 .

\section{Purification of Glycosaminoglycans from Urine}

Urines were collected and stored at $-70^{\circ} \mathrm{C}$. After thawing, 20-ml samples of urine were diluted with an equal volume of $7 \mathrm{M}$ urea $/ 10 \mathrm{mM}$ Tris- $\mathrm{HCl} \mathrm{pH} 6.8$ and applied to an ion-exchange column of $5 \times 0.5 \mathrm{~cm}$ containing $1 \mathrm{ml}$ diethylaminoethyl (DEAE)-Sepharose Fast Flow (Pharmacia, Uppsala, Sweden). After an initial wash with $3 \mathrm{ml} 0.2 \mathrm{M} \mathrm{NaCl} / 10$ $\mathrm{mM}$ Tris- $\mathrm{HCl}$ (pH 6.8), GAGs were eluted with $1 \mathrm{ml} 2 \mathrm{M} \mathrm{NaCl} / 10 \mathrm{mM}$ Tris- $\mathrm{HCl}$ (pH 6.8) followed by $3 \mathrm{ml} 10 \mathrm{mM}$ Tris- $\mathrm{HCl}$ (pH 6.8). The recov- ery of the GAGs was monitored by adding $15,000 \mathrm{dpm}\left[{ }^{35}\right.$ S]GAGs (specific activity $10^{4} \mathrm{dpm} / \mu \mathrm{g} \mathrm{GAG}$ ) to the urine. Salts were removed by ethanol precipitation of the GAGs. Five volumes of ethanol were added (final ethanol concentration $83 \%$ ) and GAGs were allowed to precipitate for $16 \mathrm{~h}$ at $-20^{\circ} \mathrm{C}$. After centrifugation for $30 \mathrm{~min}$ at $10,000 \mathrm{~g}$ $\left(-10^{\circ} \mathrm{C}\right)$, the precipitated GAGs were dried and dissolved in $2 \mathrm{ml}$ demineralized water. Recoveries were between 88 and $100 \%$. Two cycles of freezethawing of urine did not influence the results. A third cycle occasionally gave erroneous data.

\section{Quantification of Glycosaminoglycans}

Sulfated GAGs were quantified according to the method of Farndale and coworkers (23). This method is based on a metachromatic shift in absorption maximum of 1,9-dimethylmethylene blue (DMMB) (Aldrich Chemie Co., Bornem, Belgium). To $100 \mu \mathrm{l} \mathrm{GAG}$ sample, $2.5 \mathrm{ml}$ of DMMB reagent was added and the absorbance at $525 \mathrm{~nm}$ was measured immediately. The DMMB reagent contains $46 \mu \mathrm{M}$ DMMB (initially $46 \mu \mathrm{mol}$ DMMB was dissolved in $5 \mathrm{ml} 96 \%$ ethanol), $40 \mathrm{mM}$ glycine, and 42 $\mathrm{mM} \mathrm{NaCl}$, adjusted to $\mathrm{pH} 3.0$ with $1 \mathrm{M} \mathrm{HCl}$. Chondroitin 4-sulfate (Sigma, St. Louis, MO) was taken as a standard and included within each series of assays.

\section{Quantification of Total Heparan Sulfate}

Three methods for the determination of HS were used. These methods are based on different aspects of the HS structure. Bovine kidney HS (Seikagaku, Tokyo, Japan) was used as a standard.

Method 1 is a modified version of the 1,9-dimethylmethylene blue assay and is based on the backbone structure of heparan sulfate (24). Addition of bovine serum albumin and adaptation of $\mathrm{pH}$ and salt concentration of the DMMB reagent results in a specific elimination of HSbased absorbance. To $100 \mu \mathrm{l} \mathrm{GAG}$ sample, $100 \mu 13 \%$ bovine serum albumin (BSA) (in demineralized water) and $2.4 \mathrm{ml}$ of the modified DMMB
TABLE 4

LUNG FUNCTION DATA AND BODY MEASURES OF CONTROL SUBJECTS IN GROUP 1 (AGE, 51-85 YR)*

\begin{tabular}{lr}
\hline $\mathrm{BMI}, \mathrm{kg} / \mathrm{m}^{2}$ & $24.5 \pm 4.1$ \\
$\mathrm{TLC}, \%$ pred & $106 \pm 14$ \\
FRC, \% pred & $116 \pm 26$ \\
$\mathrm{RV}, \%$ pred & $110 \pm 39$ \\
$\mathrm{FEV}, \%$ pred & $94 \pm 21$ \\
$\mathrm{KCO}, \%$ pred & $92 \pm 31$
\end{tabular}

For definition of abbreviations, see Table 1.

* Values are mean \pm SD $(n=24)$.
TABLE 5

LUNG FUNCTION DATA AND BODY MEASURES OF CONTROL SUBJECTS OF GROUP 3 (AGE, 28-61)*

BMI, $\mathrm{kg} / \mathrm{m}^{2}$

TLC, \% pred

FRC, \% pred

RV, \% pred

$\mathrm{FEV}_{1}, \%$ pred

$\mathrm{KCO}, \%$ pred

$24.4 \pm 3.9$

$108 \pm 14$

$106 \pm 22$

$112 \pm 34$

$108 \pm 29$

$105 \pm 33$

For definition of abbreviations, see Table 1.

* Values are mean \pm SD $(n=37)$. 
reagent was added. This reagent contains $48 \mu \mathrm{M}$ DMMB (initially 48 $\mu \mathrm{mol}$ DMMB was dissolved in $5 \mathrm{ml} 95 \%$ ethanol), $42 \mathrm{mM}$ glycine, and $63 \mathrm{mM} \mathrm{NaCl}$, adjusted to $\mathrm{pH} 2.75$ with $1 \mathrm{M} \mathrm{HCl}$. After $30 \mathrm{~min}$ at $22^{\circ} \mathrm{C}$ the absorbance was measured at $525 \mathrm{~nm}$. By subtracting the value thus obtained (representing other GAGs) from the total GAGs, the content of HS was calculated (24).

Method 2, digestion of HS by heparitinase, is based on cleavage of glycosidic linkages in HS involving glucuronic acid residues. To lyophylized GAG samples, $25 \mu$ l heparitinase (Seikagaku, Tokyo, Japan) $(0.01$ $\mathrm{IU} / \mathrm{ml}$ containing $0.05 \mathrm{M}$ sodium acetate and $0.05 \mathrm{M}$ calcium acetate [pH 7.0]) was added. Incubation was for $16 \mathrm{~h}$ at $43^{\circ} \mathrm{C}$. The remaining GAGs were quantified using the 1,9-dimethylmethylene blue assay (see quantification of GAGs). By subtracting this value from the total GAGs the content of HS was determined.

Method 3, digestion with nitrous acid, is based on cleavage of glycosidic linkages involving hexosamine residues in which the amino groups are either $\mathbf{N}$-sulfated or unsubstituted. Nitrous acid digests HS and heparin, but not other GAGs (25). Purified GAGs were treated for 90 min at $22^{\circ} \mathrm{C}$ with nitrous acid prepared by mixing equal volumes of $5 \%$ (wt/vol) $\mathrm{NaNO}_{2}$ and $1.5 \mathrm{M} \mathrm{HCl}$. The residual GAGs were quantified using the 1,9-dimethylmethylene blue assay (see quantification of GAGs). By subtracting this value from the the total GAG the content of HS and heparin was obtained. The contribution of heparin is negligible.

\section{Quantification of the HS JM403 Epitope}

The HS JM403 epitope, defined by monoclonal antibody (mAb) JM403 $(26,27)$, was quantitated using an inhibition enzyme immunoassay (Figure 1). In the wells of polystyrene microtiter plates (Greiner GmbH, Frickenhausen, Germany; catalog number 655061 ), $100 \mu$ l of ascites containing $\mathrm{mAb}$ JM403 (diluted 1:40,000 in Tris-buffered saline containing $0.1 \%$ Tween 20 and $1 \%$ [wt/vol] bovine serum albumin, pH 7.5 [TBST/BSA]) was mixed with $100 \mu$ lyophylized GAG sample and incubated overnight at $4^{\circ} \mathrm{C}$. We transferred $100 \mu \mathrm{l}$ of each well to a corresponding well of a polystyrene plate previously coated with $1 \mu \mathrm{g} \mathrm{HS}$ and incubated

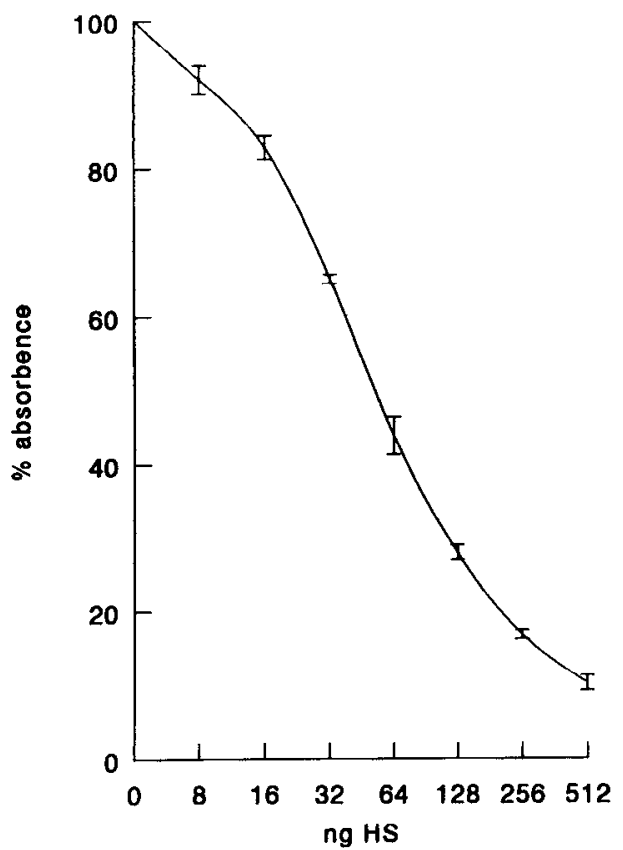

Figure 1. Standard curve for the inhibition immunoassay for the heparan sulfate epitope JM403. A volume of $100 \mu$ l containing various amounts of bovine kidney HS was incubated for $16 \mathrm{~h}$ at $4^{\circ} \mathrm{C}$ with $50 \mu \mathrm{l}$ of JM403 antibody. Next, $100 \mu \mathrm{l}$ of this mixture was transferred to a well previously coated with $1 \mu \mathrm{g} \mathrm{HS}$. After incubation for $2 \mathrm{~h}$ at $22^{\circ} \mathrm{C}$, the antibodies bound to the well were detected by addition of alkaline phosphatase-conjugated secondary antibodies. After addition of substrate the color developed was spectrophotometrically measured at $405 \mathrm{~nm}$. Data are mean $\pm S D(n=3)$. for $2 \mathrm{~h}$. Free antibodies, i.e., antibodies not bound by HS of the sample, were allowed in this way to complex with the coated HS. After washing thrice with TBST, bound antibodies were detected by incubation for $1 \mathrm{~h}$ at $22^{\circ} \mathrm{C}$ with $100 \mu \mathrm{l}$ rabbit anti-mouse Ig (Dako, Glostrup, Denmark) conjugated with alkaline phosphatase (diluted 1:2,000 in TBST/BSA). After washing again, $100 \mu \mathrm{l}$ of substrate $(1 \mathrm{mg} / \mathrm{ml}$-nitrophenylphosphate in $1 \mathrm{M}$ diethanolamine ( $\mathrm{pH} \mathrm{9.8)} \mathrm{containing} 50 \mathrm{mM} \mathrm{MgCl}_{2}$ ) was added, and the reaction was allowed to proceed for $2 \mathrm{~h}$ at $22^{\circ} \mathrm{C}$. The color developed was spectrophotometrically measured at $405 \mathrm{~nm}$. Bovine kidney HS was taken as a standard within each series. One unit is defined as the amount of epitope present on $1 \mu \mathrm{g}$ bovine kidney heparan sulfate.

Samples were analyzed in triple and at least three different twofold dilutions were applied such that three points were in the steep part of the standard curve. Samples of patients and control subjects were analyzed on the same microtiter plate. The intra- and interassay coefficients of variation were 5.2 and $12.6 \%$, respectively.

\section{Other Procedures}

Urinary creatinine was determined using the alkaline picrate method (procedure number 555; Sigma, St. Louis, MO).

\section{Statistical Analysis}

Values are given as mean \pm SEM, unless indicated otherwise. Intergroup comparison was calculated using the Mann-Whitney test. Correlation analysis was performed using Spearman's rank correlation test. $P$ values less than 0.05 were considered significant.

\section{RESULTS}

Pilot experiments showed that the urinary content of HS JM403 epitope and of HS on base of creatinine remained constant during the day, and from day to day. This also holds for GAGs, which is in agreement with data from the literature (28). There was no correlation between age and urinary content of HS and GAG. There was, however, a correlation between age and content of HS JM403 epitope ( $r=0.26, p<0.03$ ).

In patients with COPD the content of urinary GAGs was not altered compared with controls (Figure 2, Table 6). The urinary content of HS, measured by three different methods, was also not changed (Figure 3, Table 6). The urinary content of the HS JM403 epitope was significantly decreased in patients with COPD (Figure 4, Table 6).

To examine the specificity of this finding, we studied two additional groups of patients: patients with bronchial carcinoma with and without emphysema, and patients with sarcoidosis. The

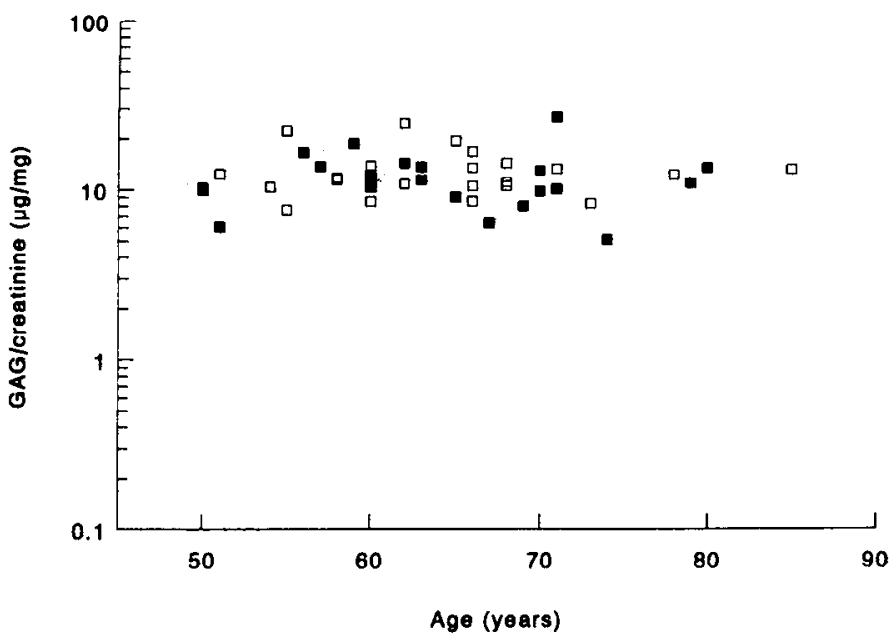

Figure 2. Glycosaminoglycan content in the urine of individual control subjects and patients with COPD. Open squares: control; closed squares: patient with COPD. 
TABLE 6

URINARY CONTENT OF GLYCOSAMINOGLYCANS, HEPARAN SULFATE, AND HEPARAN SULFATE JM403 EPITOPE OF CONTROL SUBJECTS AND PATIENTS WITH COPD*

\begin{tabular}{lccc}
\hline $\begin{array}{l}\text { Content } \\
\text { (per } m g \text { creatinine })\end{array}$ & $\begin{array}{c}\text { Controls } \\
(n=20-24)\end{array}$ & $\begin{array}{c}\text { Patients } \\
(n=20)\end{array}$ & Significance \\
\hline $\begin{array}{l}\text { Glycosaminoglycan, } \mu \mathrm{g} \\
\text { Heparan sulfate }\end{array}$ & $12.7 \pm 0.9$ & $11.9 \pm 1.1$ & NS \\
$\quad$ Modified DMMB assay, $\mu \mathrm{g}$ & $5.1 \pm 0.5$ & $5.0 \pm 0.5$ & $\mathrm{NS}$ \\
Heparitinase assay, $\mu \mathrm{g}$ & $5.1 \pm 0.7$ & $6.4 \pm 0.8$ & $\mathrm{NS}$ \\
Nitrous acid assay, $\mu \mathrm{g}$ & $3.3 \pm 0.5$ & $3.8 \pm 0.4$ & $\mathrm{NS}$ \\
JM403 epitope, U & $4.1 \pm 0.7$ & $0.6 \pm 0.1$ & $\mathrm{p}<0.0001$ \\
\hline
\end{tabular}

NS $=$ not significant

* Values are mean \pm SD SEM. Characteristics of control subjects are given in Table 4, of patients in Table 1
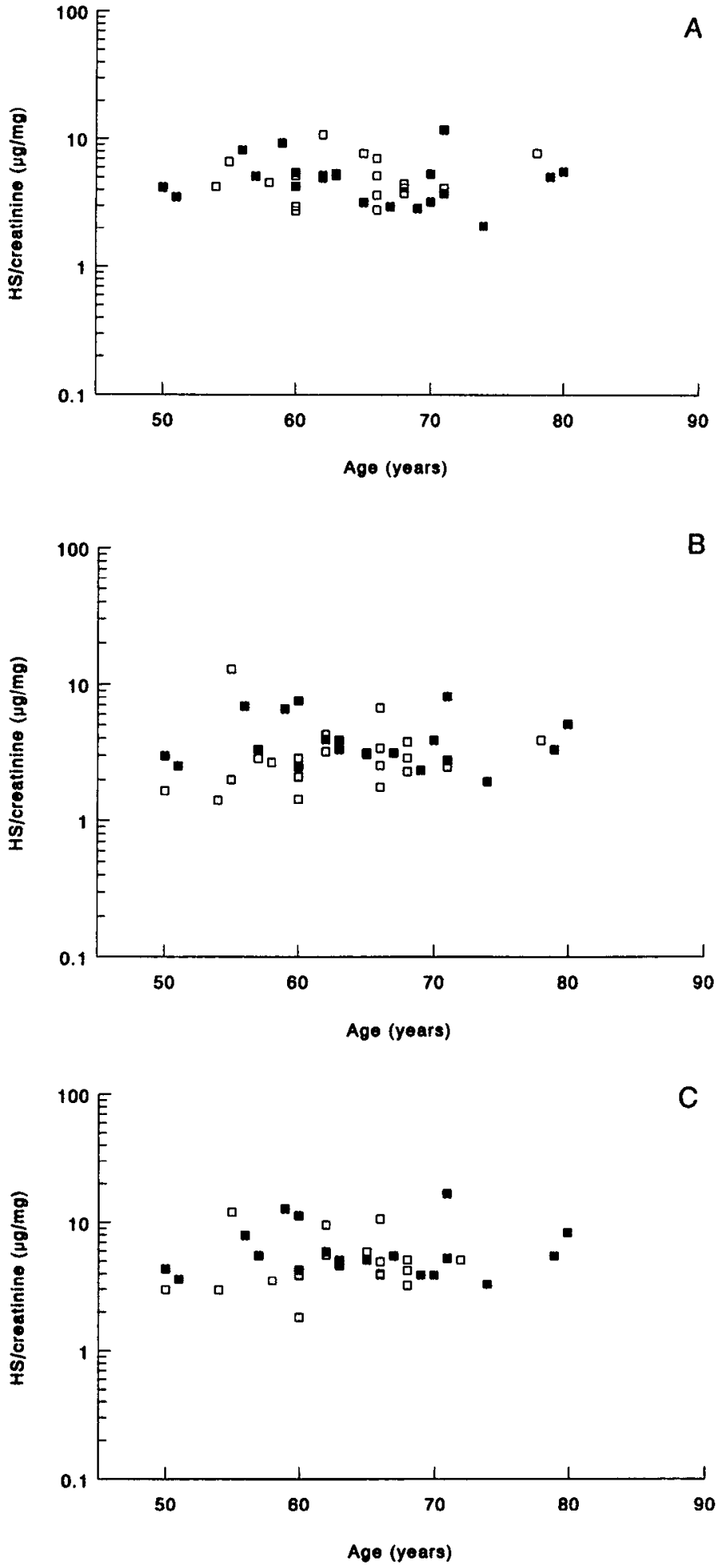

Figure 3. Heparan sulfate content in the urine of individual control subjects and patients with COPD measured using $(A)$ a modified 1,9dimethylmethylene blue assay; $(B)$ nitrous acid digestion; $(C)$ heparitinase digestion. Open squares: control; closed squares: patient with COPD.

tope is basement membrane specific (26). In lung the proportion of JM403 epitope per milligram of HS is quite high, e.g., in rat lung 35-fold higher than in kidney and heart (Van Den Born and coworkers, unpublished data). 


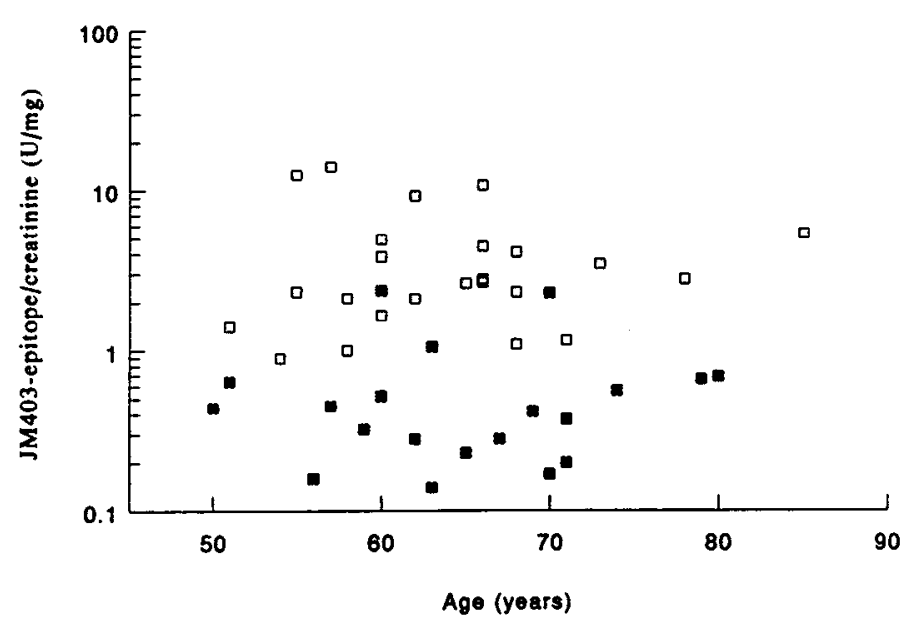

Figure 4. Heparan sulfate JM403 epitope content in the urine of individual control subjects and patients with COPD. One unit is defined as the amount of epitope present on $1 \mu \mathrm{g}$ bovine kidney heparan sulfate. Open squares: control; closed squares: patient with COPD.

The normal content of HS and the decreased content of the HS JM403 epitope, suggest a structural alteration in or an altered processing of the HS molecule in the lungs of emphysematous patients. At present, we do not know the exact nature of the epitope recognized by the JM403 antibody. Studies on chemically and enzymatically modified HS indicate that the epitope contains one or more $N$-unsubstituted glucosamine and D-glucuronic acid units, and is located in a region of the heparan sulfate chain composed of mixed $N$-sulfated and $N$-acetylated disaccharide units (30). The biologic significance of $N$-unsubstituted glucosamines has recently been demonstrated in the binding of HS to I-selectin (31). Blocking of the epitope in the glomerular basement membrane by injection of JM403 antibody leads to proteinuria in rats (27). Interestingly, microalbuminuria has recently been described in a small group of patients with COPD (32).

The etiology of pulmonary emphysema is not known. Considering that the development of (clinically evident) emphysema is a process of several decades, the basic alteration may be quantitatively small in nature. The decreased content of a specific epitope of HS, together with a normal content of total HS, in the

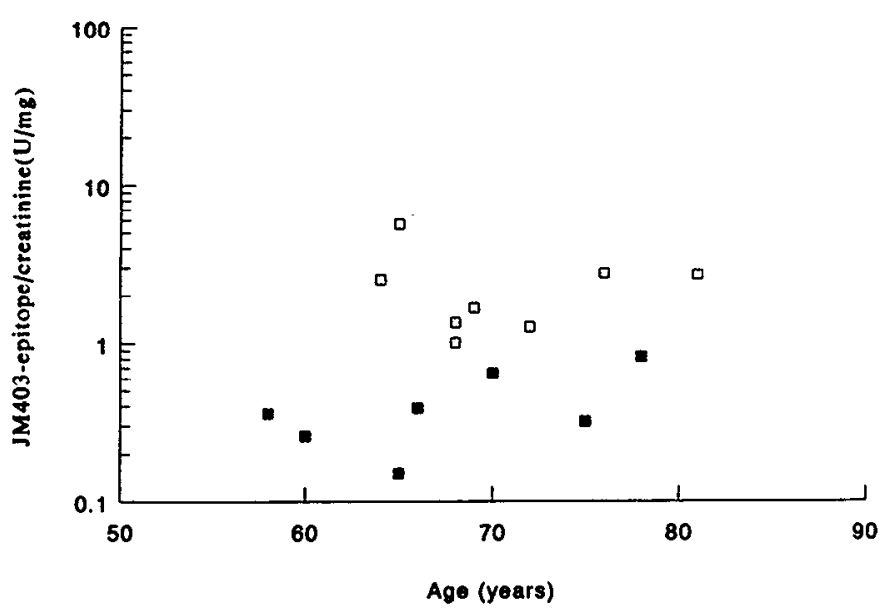

Figure 5. Heparan sulfate JM403 epitope content in the urine of individual patients with bronchial carcinoma with and without emphysema. Open squares: patient without emphysema; closed squares: patient with emphysema.

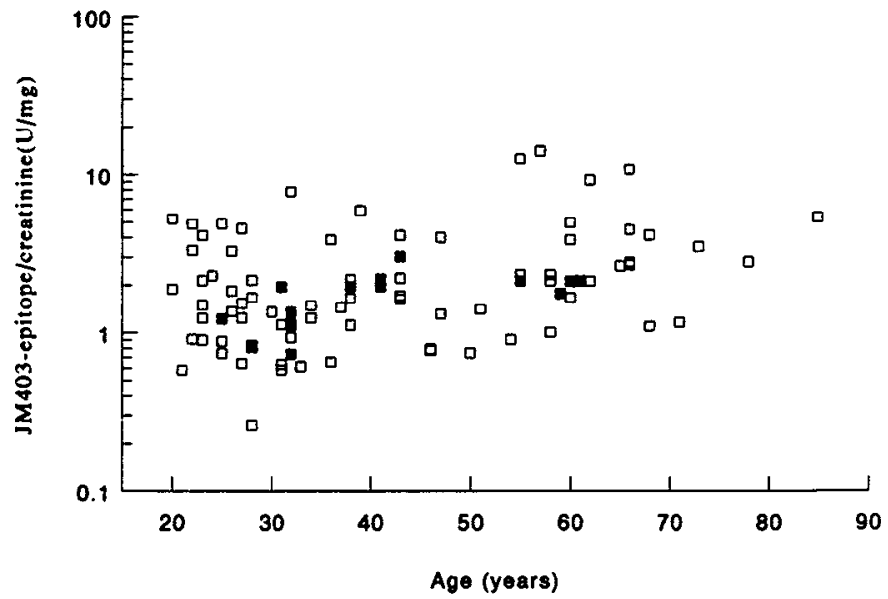

Figure 6. Heparan sulfate JM403 epitope content in the urine of individual control subjects and patients with sarcoidosis. Open squares: control; closed squares: patient with sarcoidosis.

urines of emphysema patients hints at a small, but significant alteration. Alterations in the HS molecule would have consequences for the protecting HS-proteoglycan barrier of the alveolus (14). In view of the functions of HS (antiprotease activity, binding and modulation of growth factors and cytokines, involvement in the fibrillogenesis of collagen and elastin), this could lead to a destabilization of the extracellular matrix, ultimately resulting in emphysematous lesions. This concept is supported by the findings in rats that specific inhibition of proteoglycan synthesis induces emphysematous lesions (33) and that HS proteoglycans are very vulnerable toward elastase degradation (34). In a genetic model for emphysema, the tight-skin mouse, antibodies to HS have been detected (35).

TABLE 7

URINARY CONTENT OF GLYCOSAMINOGLYCANS, HEPARAN SULFATE, AND HEPARAN SULFATE IM403 EPITOPE OF PATIENTS WITH BRONCHIAL CARCINOMA WITH AND WITHOUT EMPHYSEMA*

\begin{tabular}{lccc}
\hline $\begin{array}{l}\text { Content } \\
\text { (per } m g \text { creatinine) }\end{array}$ & $\begin{array}{c}\text { Patients without } \\
\text { Emphysema } \\
(n=8)\end{array}$ & $\begin{array}{c}\text { Patients with } \\
\text { Emphysema } \\
(n=7)\end{array}$ & Significance \\
\hline $\begin{array}{l}\text { Glycosaminoglycan, } \mu \mathrm{g} \\
\text { Heparan sulfate }\end{array}$ & $16.7 \pm 2.4$ & $16.5 \pm 2.2$ & NS \\
$\begin{array}{l}\text { Modified DMMB assay, } \mu \mathrm{g} \\
\text { Epitope JM403, U }\end{array}$ & $6.4 \pm 0.7$ & $6.6 \pm 0.7$ & NS \\
\hline
\end{tabular}

NS $=$ not significant.

* Values are mean \pm SEM. Characteristics of patients are given in Table 2.

TABLE 8

URINARY CONTENT OF GLYCOSAMINOGLYCANS, HEPARAN SULFATE, AND HEPARAN SULFATE JM403 EPITOPE OF CONTROL SUBJECTS AND PATIENTS WITH SARCOIDOSIS

\begin{tabular}{lccc}
\hline $\begin{array}{l}\text { Content } \\
\text { (per } m g \text { creatinine) }\end{array}$ & $\begin{array}{l}\text { Controls } \\
(n=41)\end{array}$ & $\begin{array}{c}\text { Patients } \\
(n=15)\end{array}$ & Significance \\
\hline $\begin{array}{l}\text { Clycosaminoglycan, } \mu \mathrm{g} \\
\text { Heparan sulfate }\end{array}$ & $14.3 \pm 0.5$ & $12.8 \pm 0.9$ & NS \\
$\begin{array}{l}\text { Modified DMMB assay, } \mu \mathrm{g} \\
\text { Epitope IM403, U }\end{array}$ & $4.3 \pm 0.3$ & $3.0 \pm 1.0$ & NS \\
& $2.4 \pm 0.4$ & $1.7 \pm 0.2$ & NS \\
\hline
\end{tabular}

$N S=$ not significant.

* Values are mean \pm SEM. Characteristics of control subjects are given in Table 5, of patients in Table 3. 
In conclusion, urines from patients with COPD/emphysema contain normal levels of GAGs and HS, but on the excreted HS the expression of a specific epitope is decreased. Considering the physiologic role of HS in alveoli, this alteration may be associated with the pathogenesis of emphysema. Future research will focus on structural analysis of heparan sulfate from the lung parenchyma of patients with emphysema and on the usefulness of the HS JM403 epitope for early diagnosis of emphysema.

Acknowledgment: The writers express their gratitude to Ronald Moers for excellent practical assistance.

\section{References}

1. Snider, G. L. 1992. Emphysema: the first two centuries - and beyond. A historical overview, with suggestions for future research: part 2. Am. Rev. Respir. Dis. 146:1615-1622.

2. Dillon, T. J., R. L. Walsh, R. Scicchitano, B. Eckert, E. G. Clearly, and G. McLennan. 1992. Plasma elastin-derived peptide levels in normal adults, children, and emphysematous subjects. Physiologic and computed tomographic scan correlates. Am. Rev. Respir. Dis. 146: 1143-1148.

3. Akers, S., U. Kuchick, M. Swartz, G. Rosen, M. Glass, J. Rosenboom, P. Kimbel, and G. Weinbaum. (1992). Specificity and sensitivity of the assay for elastin-derived peptides in chronic obstructive pulmonary disease. Am. Rev. Respir. Dis. 145:1077-1081.

4. Pelham, F., M. Wewers, R. Crystal, A. S. Buist, and A. Janoff, 1985. Urinary excretion of desmosine (elastin cross-links) in subjects with PiZZ alpha-1-antitrypsin deficiency, a phenotype associated with hereditary predisposition to pulmonary emphysema. Am. Rev. Respir. Dis. 132:821-823.

5. Pai, V., A. Guz, and G. J. Phillips. 1991. Urinary desmosine, elastolysis, and lung disease. Metab. Clin. Exp. 40:139-145.

6. Frette, C., S. M. Wei, F. Neukirch, R. Sesboue, J. P. Martin, M. P. Jacob, and F. Kauffmann. 1992. Relation of serum elastin peptide concentration to age, $\mathrm{FEV}_{1}$, smoking habits, alcohol consumption, and protease inhibitor phenotype. An epidemiological study in working men. Thorax 47:937-942.

7. Vogel, K. G., M. Paulsson, and D. Heinegard. 1984. Specific inhibition of type I and II collagen fibrillogenesis by the small proteoglycans of tendon. Biochem. J. 223:587-597.

8. Danielsen, C. C. 1982. Mechanical properties of reconstituted collagen fibrils. Connect. Tissue Res. 9:219-225.

9. McGowan, S. E., R. G. Liu, and C. S. Harvey. 1993. Effects of heparin and other glycosaminoglycans on elastin production by cultured neonatal rat lung fibroblasts. Arch. Biochem. Biophys. 302:322-331.

10. Sannes, P. L., K. K. Burch, and J. Khosla. 1992. Immunohistochemical localization of epidermal growth factor and acidic and basic fibroblast growth factors in postnatal developing and adult rat lungs. Am. J. Respir. Cell Mol. Biol. 7:230-237.

11. Redini, F., C. Lafuma, W. Hornebeck, J. Choay, and L. Robert. 1988. Influence of heparin fragments on the biological activities of elastase(s) and $\alpha_{1}$ proteinase inhibitor. Biochem. Pharmacol. 37:4257-4261.

12. Rao, N. V., T. P. Kennedy, N. K. Y. Rao, and J. R. Hoidal. 1990. Sulfated polysaccharides prevent human leucocyte elastase-induced acute lung injury and emphysema in hamsters. Am. Rev. Respir. Dis. 142:407-412.

13. Walsh, R. L., T. J. Dillon, R. Scicchitano, and G. McLennan. 1991. Heparin and heparan sulphate are inhibitors of human leucocyte elastase. Clin. Sci. 81:341-346.

14. Van Kuppevelt T. H. M. S. M., F. P. M. Cremers, J. G. W. Domen, H. M. Van Beuningen, A. J. C. Van den Brule, and C. M. A. Kuyper. 1985. Ultrastructural localization and characterization of proteoglycans in human lung alveoli. Eur. J. Cell Biol. 36:74-80.

15. Van Kuppevelt, T. H. M. S. M., H. M. Van Beuningen, T. L. M. Rutten, A. J. C. Van den Brule, and C. M. A. Kuyper. 1987. Further characterization of a large proteoglycan in human lung alveoli. Eur. J. Cell Biol. 39:386-390.

16. Konno, K., H. Arai, M. Motomiya, H. Nagai, M. Ito, H. Sato, and K. Satoh. 1982. A biochemical study on glycosaminoglycans (muco- polysaccharides) in emphysematous and in aging lungs. Am. Rev. Respir. Dis. 126:797-801.

17. Pecora, L. J., W. R. Manne, G. L. Baum, D. P. Feldman, and S. Recavarren. 1967. Biochemical study of ground substance in normal and emphysematous lungs. Am. Rev. Respir. Dis. 95:623-630.

18. Laros, C. D., C. M. A. Kuyper, and H. M. J. Janssen. 1972. The chemical composition of fresh human lung parenchyma. An approach to the pathogenesis of lung emphysema. Respiration 29:458-467.

19. Saltzman, H. A., M. K. Schauble, and H. O. Sieker. 1961. Hexosamine content of aged and chronically diseased lung. J. Lab. Clin. Med. 58:115-121.

20. Karlinski, J. B., J. Fredette, G. Davidovits, A. Catanese, R. Snider, B. Faris, G. L. Snider, and C. Franzblau. 1983. The balance of lung connective tissue elements in elastase-induced emphysema. Lab. Clin. Med. 102:151-162.

21. Lafuma, C., M. Moczar, F. Lange, and L. Robert. 1985. Biosynthesis of hyaluronic acid, heparan sulfate and structural glycoproteins in hamster lung explants during elastase induced emphysema. Connect. Tissue Res. 13:169-179.

22. Quanjer, P. H., editor. 1993. Standardized lung function testing. Eur. Respir. J. 6(Suppl. 16):1-100.

23. Farndale, R. W., D. J. Buttle, and A. J. Barrett. 1986. Improved quantitation and discrimination of sulfated glycosaminoglyans by use of dimethylmethylene blue. Biochim. Biophys. Acta 883:173-177.

24. Van de Lest, C. H. A., E. M. M. Versteeg, J. H. Veerkamp, and T. H. Van Kuppevelt. 1994. A spectrophotometric method for the determination of heparan sulphate. Biochim. Biophys. Acta 1201:305-311.

25. Beeley, J. G. 1985. Glycoproteins and proteoglycan techniques. 1985. In R. H. Burdon and P. H. Van Knippenberg, editors. Laboratory Techniques in Biochemistry and Molecular Biology, Vol. 16. Elsevier, Amsterdam, New York, Oxford.

26. Van den Born, J., L. P. W. J. Van den Heuvel, M. A. H. Bakker, J. H. Veerkamp, K. J. M. Assmann, and J. H. M. Berden. 1994. Monoclonal antibodies against the protein core and glycosaminoglycan side chain of glomerular basement membrane heparan sulfate proteoglycan: characterization and immunohistological application in human tissue. J. Histochem. Cytochem. 42:89-102.

27. Van den Born, J., L. P. W. J. Van den Heuvel, M. A. H. Bakker, J. H. Veerkamp, K. J. M. Assmann, and J. H. M. Berden. 1992. A monoclonal antibody against GBM heparan sulfate induces an acute selective proteinuria in rats. Kidney Int. 41:115-123.

28. Dembure, P. P., and R. A. Roesel. 1991. Screening for mucopolysaccharidoses by analysis of urinary glycosaminoglycans. In Techniques in Diagnostic Human Biochemical Genetics: A Laboratory Manual. Wiley-Liss, New York. 77-86.

29. Stone, P. J., D. J. Gottlieb, G. T. O'Connor, D. E. Ciccolella, R. Breuer, J. Bryan-Rhadfi, H. A. Shaw, C. Franzblau, and G. L. Snider. 1995. Elastin and collagen degradation products in urine of smokers with and without chronic obstructive pulmonary disease. Am. J. Respir. Crit. Care Med. 151:952-959.

30. Van Den Born, J., K. Gunnarsson, M. A. H. Bakker, L. Kjellén, M. Kusche-Gullberg, M. Maccarana, J. H. M. Berden, and U. Lindahl. 1995. Presence of $N$-unsubstituted glucosamine units in native heparan sulfate revealed by a monoclonal antibody. J. Biol. Chem. 270: 31303-31309.

31. Norgard-Sumnicht, K., and A. Varki. 1995. Endothelial heparan sulfate proteoglycans that bind to L-selectin have glucosamine residues with unsubstituted amino groups. J. Biol. Chem. 270:12012-12024.

32. Wilkinson, R., J. S. Milledge, and M. J. Landon. 1993. Microalbuminuria in chronic obstructive lung disease. B.M.J. 307:239.

33. Van de Lest, C. H. A., E. M. M. Versteeg, J. H. Veerkamp, and T. H. M. S. M. Van Kuppevelt. 1992. The role of proteoglycans in the induction of pulmonary emphysema. Proceedings of the XIIth Meeting of the Federation of European Connective Tissue Societies, Davos, Switzerland, abstract 4/26.

34. Van de Lest, C. H. A., E. M. M. Versteeg, J. H. Veerkamp, and T. H. Van Kuppevelt. 1995. Digestion of proteoglycans in porcine pancreatic elastase-induced emphysema in rats. Eur. Respir. J. 8:238-245.

35. Dimitriubona, A., and H. Fillit. 1993. Studies of the cellular immune response to heparan sulfate proteoglycan in the tight skin mouse. Cell. Immunol. 150:321-332. 